\title{
Effects of Nutritional Supplements on Judo-Related Performance: A Review
}

\author{
by \\ Leonardo Simoncini ${ }^{1}$ Ángel Lago-Rodríguez², Álvaro López-Samanes ${ }^{3}$, \\ Alberto Pérez-López ${ }^{4}$,Raúl Domínguez ${ }^{5,6,7}$
}

The potential ergogenic effect of nutritional supplements depends on their dosage and the type of exercise executed. Aiming at reviewing the research literature regarding sport supplements utilized in judo in order to improve performance, a literature search was performed at the following databases: Dialnet, PubMed, Scielo, Scopus and SportDiscus. A total of 11 articles met the inclusion criteria and were selected. Evidence revised indicates that supplementation with caffeine, $\beta$-alanine, sodium bicarbonate, creatine, and $\beta$-hydroxy- $\beta$-methylbutyrate has a positive effect on judo-related performance. Moreover, there is evidence suggesting that combining some of these nutritional supplements may produce an additive effect.

Key words: sport nutrition, ergogenic supplementation, combat sports performance.

\section{Introduction}

Judo is an Olympic combat sport in which athletes perform multiple high-intensity intermittent efforts aiming at either throwing their opponent to the ground or controlling him/her in groundwork through pin or submission (Franchini et al., 2014). Judo combats conclude when an ippon (perfect throw) is achieved or when the combat time is fulfilled (4 min according to the International Judo Federation). Judo combats have mean duration of $\sim 3 \mathrm{~min}$, during which efforts of $\sim 30 \mathrm{~s}$ are interspersed with $\sim 10 \mathrm{~s}$ of rest intervals; thus, having the activity-to-rest ratio of 2:1 or 3:1 (Franchini et al., 2013). Moreover, due to the specific organization of judo's tournaments, athletes need to perform several combats during the same day, with recovery time among combats varying from few minutes to several hours (Artioli et al., 2010b).
Body mass and body composition have been associated with higher performance in judo (Kim et al., 2011). Also, higher relative bone mass and a larger percentage of muscle mass are associated with greater judo-specific performance test results (Casals et al., 2017). Thus, in order to ensure similar levels of agility, strength, and power between opponents, judo athletes are grouped into seven weight categories (Artioli et al., 2010a; Franchini et al., 2011). Judokas aware of the advantage of competing against lighter, smaller, and weaker opponents, implement strategies to reduce their body mass before the competition (Artioli et al., 2010a).

As in most combat sports, technique and physical fitness play a crucial role in judo performance. Particularly, both the aerobic and anaerobic systems are required during judo combats. Strength and power are essential to

1 - Faculty of Health Sciences, Alfonso X El Sabio University. Madrid. Spain.

2 - Facultad de Ciencias de la Salud de la Universidad Isabel I. www.ui1.es. Burgos. Spain.

3 - School of Physiotherapy, Faculty of Health Sciences, Francisco de Vitoria University. Madrid. Spain.

4 - Department of Biomedical Sciences. Faculty of Medicine and Health Sciences. University of Alcalá. Madrid. Spain.

5 - Escuela Universitaria de Osuna (Centro adscrito a la Universidad de Sevilla) Osuna, Sevilla. Spain

6 - Departamento de Educación Física y Deporte, Universidad de Sevilla. Sevilla. Spain

7 - Studies Research Group in Neuromuscular Responses (GEPREN), University of Lavras Lavras. Brazil 
execute effective judo techniques, whereas the aerobic capacity allows athletes to recover both between combats and particular efforts accomplished within a combat (Franchini et al., 2013). Due to the high-intensity intermittent efforts that judokas perform during a combat, with the activity-to-rest ratio between $2: 1$ and 3:1, it is reasonable to suggest that ATP availability is mainly facilitated by phosphocreatine (PCr) and glycolysis.

It should be noted that only $70 \%$ of phosphocreatine stores are replenished during the initial $30 \mathrm{~s}$ of recovery intervals, needing from 3 to 5 minutes to achieve a complete restoration (Tomlin and Wenger, 2001). Considering that judokas have brief recovery periods of $\sim 10 \mathrm{~s}$ of duration within bouts (Franchini et al., 2013), it is reasonable to suggest that phosphocreatine depletion is a limiting factor of performance in judo. Furthermore, decreased $\mathrm{pH}$ levels that follow an increased production of $\mathrm{H}+$ ions, resulting from the central contribution of the glycolytic metabolism in judo (Franchini et al., 2011) may also compromise judo-related performance (Artioli et al., 2010a).

Performance in high-level competitive sports is so balanced that small differences have been shown to determine an athlete's chances of winning. Thus, many athletes consume dietary supplements aiming to optimize their performance, especially among elite athletes (Huang et al., 2006). It has been established that elite athletes consume dietary supplements with the objective to: i) increase power; ii) prevent nutritional deficits; iii) maintain health condition; iv) prevent from injuries; and v) improve sport performance (Maughan et al., 2018).

High quality scientific evidence for the improvement of sport performance has only been reported for the following dietary supplements (Maughan et al., 2018): caffeine, creatine, $\beta$ alanine, sodium bicarbonate (NaHCO3), and beetroot juice/nitrate. However, the potential ergogenic effect of these dietary supplements is associated with the practice of a specific sport modality, since it is conditioned by the type of effort executed (López-González et al., 2018). To the best of the authors' knowledge, no previous literature review has addressed the effects of nutritional supplementation on judo-related performance. Therefore, this study aimed at examining research literature evaluating the effects of different types of nutritional supplements on performance of judo athletes.

\section{Methods}

The literature search was carried out in the following databases: Dialnet, Pubmed, Scielo, Scopus and SportDiscus. The search was limited to articles published between 2010 and January $8^{\text {th }}$, 2019. The search strategy used was (concept 1) (judo OR judoka OR "combat Sports") AND (concept 2) (supplement* OR nutr* OR "ergogenic aid").

The title and abstract of every document resulting from the search strategy were read, and duplicates were discarded. Articles that did not present original interventions were also excluded, and only articles written in English, Spanish or Portuguese were included.

A series of exclusion criteria were then applied, rejecting animal studies, research conducted "in vitro" or with cell cultures, studies that did not include an ergogenic supplementation protocol and a comparison with a placebo condition, studies conducted on samples that did not include judokas, and studies where no judo-related performance variable was registered.

\section{Results}

A total of 400 articles were identified by the initial search. After excluding duplicates $(\mathrm{n}=$ 276), articles written in a language different from English, Spanish or Portuguese, and those which presented non-original experimental studies (i.e.: patents, books, editorials, congress abstracts and presentations, reviews and meta-analysis), a total of 236 documents were potentially eligible for this review (Figure 1).

After reading each of these 236 articles and applying the exclusion criteria, a total of 12 articles were finally selected for review (Artioli et al., 2007; Astley et al., 2017; de Andrade Kratz et al., 2017; Durkalec-Michalski et al., 2017; Felippe et al., 2016; Hung et al., 2010; Lopes-Silva et al., 2014; Lopez-Grueso et al., 2014; Souissi et al., 2012, 2015; Sterkowicz et al., 2012; Tobias et al., 2013) (Figure 1). However, one article was later excluded, since no $p$-values were specified for each of the performed statistical tests (LopezGrueso et al., 2014). 
Table 1a

Summary of significant results reported by studies evaluating the ergogenic effects of Caffeine and $\beta$-alanine on performance in judo athletes.

\begin{tabular}{|c|c|c|c|c|}
\hline Cite & Sample & $\begin{array}{l}\text { Supplementation } \\
\text { protocol }\end{array}$ & Performance test & Results \\
\hline \multicolumn{5}{|c|}{ Caffeine } \\
\hline $\begin{array}{l}\text { Astley } \\
\text { et al. } \\
(2017)\end{array}$ & $\begin{array}{l}\text { Teen- } \\
\text { judokas } \\
\text { competing } \\
\text { at the } \\
\text { national } \\
\text { level } \\
(\mathrm{n}=18)\end{array}$ & $\begin{array}{l}\text { EC1: } 4 \mathrm{mg} / \mathrm{kg} \text { CAFF } \\
\text { (60 min before test) } \\
\text { EC2: PLAC }\end{array}$ & SJFT & $\begin{array}{l}\text { EC1 increased TNT compared to EC2 } \\
(+31 \% ; 29.0 \pm 2.6 \text { vs. } 22.1 \pm 3.4 ; p<0.01) \\
\text { EC1 reduced SJFT index compared to EC2 } \\
(-22 \% ; 12.2 \pm 0.5 \text { vs. } 15.7 \pm 0.9 ; p<0.001) \\
\text { EC1 reduced RPE compared to EC2 }(-15 ; \\
7.0 \pm 0.1 .1 \text { vs. } 8.2 \pm 2.0 ; p<0.05)\end{array}$ \\
\hline $\begin{array}{l}\text { Lopes- } \\
\text { Silva } \\
\text { et al. } \\
(2014)\end{array}$ & $\begin{array}{l}\text { Experienc } \\
\text { ed } \\
\text { judokas } \\
(\mathrm{n}=6)\end{array}$ & $\begin{array}{l}\text { EC1: } 6 \mathrm{mg} / \mathrm{kg} \text { CAFF } \\
(60 \mathrm{~min} \text { before test) } \\
\text { ingested after the } \\
\text { weight loss protocol } \\
\text { EC2: PLAC ingested } \\
\text { after the weight loss } \\
\text { protocol } \\
\text { EC3: control (no } \\
\text { supplementation; no } \\
\text { weight loss) }\end{array}$ & $\begin{array}{l}3 \times \text { SJFT }(5-\mathrm{min} \\
\text { recovery period) }\end{array}$ & $\begin{array}{l}\text { No significant differences between } \\
\text { experimental conditions were found for } \\
\text { the performance variables. }\end{array}$ \\
\hline $\begin{array}{l}\text { Souissi } \\
\text { et al. } \\
(2012) \\
\end{array}$ & $\begin{array}{l}\text { Elite } \\
\text { judokas } \\
(\mathrm{n}=10)\end{array}$ & $\begin{array}{l}\text { EC1: } 5 \mathrm{mg} / \mathrm{kg} \text { CAFF } \\
\text { ( } 60 \mathrm{~min} \text { before test) } \\
\text { EC2: PLAC }\end{array}$ & $\begin{array}{l}\text { Simple reaction } \\
\text { time test } \\
\text { Wingate test } \\
\end{array}$ & $\begin{array}{l}\text { EC1 reduced reaction time compared to } \\
\text { EC2 }(-13 \% ; 0.26 \pm 0.03 \text { vs. } 0.3 \pm 0.03 \mathrm{~ms} ; p< \\
0.05)\end{array}$ \\
\hline $\begin{array}{l}\text { Souissi } \\
\text { et al. } \\
(2015)\end{array}$ & $\begin{array}{l}\text { Elite } \\
\text { judokas } \\
(\mathrm{n}=12)\end{array}$ & $\begin{array}{l}\text { EC1: } 5 \mathrm{mg} / \mathrm{kg} \text { CAFF } \\
\text { (60 min before test) } \\
\text { EC2: PLAC }\end{array}$ & $\begin{array}{l}\text { Simple reaction } \\
\text { time test } \\
\text { Wingate test }\end{array}$ & $\begin{array}{l}\text { EC1 significantly reduced simple reaction } \\
\text { time compared to EC2 }(-12 \% ; 0.30 \pm 0.04 \\
\text { vs. } 0.34 \pm 0.03 \mathrm{~ms} ; p<0.001) \\
\text { Wingate Test: } \\
-\mathrm{W}_{\text {peak significantly increased at EC1 }} \\
\text { compared to EC2 }(+8 \% 11.01 \pm 2.46 \text { vs. } \\
\left.10.21 \pm 2.61 \mathrm{~W} \cdot \mathrm{kg}^{-1} ; p<0.001\right) \\
-\mathrm{W}_{\text {avg significantly increased at EC1 }} \text { compared to EC2 }(+7 \% ; 7.88 \pm 0.9 \text { vs. } 7.36 \pm \\
\left.1.25 \mathrm{~W} \cdot \mathrm{kg}^{-1} ; p<0.05\right)\end{array}$ \\
\hline \multicolumn{5}{|c|}{$\beta$-alanine } \\
\hline $\begin{array}{l}\text { De } \\
\text { Andra } \\
\text { de } \\
\text { Kratz } \\
\text { et al. } \\
(2017)\end{array}$ & $\begin{array}{l}\text { Judokas at } \\
\text { the } \\
\text { national } \\
\text { and } \\
\text { internatio } \\
\text { nal level } \\
(\mathrm{n}=23)\end{array}$ & $\begin{array}{l}4 \quad \text { weeks } \\
\text { supplementation } \\
\text { EG1: } 1.6 \quad \mathrm{~g} \quad \beta- \\
\text { alanine/day }(\mathrm{n}=12) \\
\text { EG2: } P \text { PLAC }(\mathrm{n}=11)\end{array}$ & $\begin{array}{l}3 \times \text { SJFT } \quad \text { (pre- } \\
\text { and } \\
\text { supplementation } \\
\text { ) }\end{array}$ & $\begin{array}{l}\text { - EG1 increased TNT at post compared to } \\
\text { pre }(\sim 8 \% ; \sim 79.0 \text { vs. } \sim 72.9 ; p<0.001) \text {. } \\
-\quad \text { TNT was larger at post for EG1 } \\
\text { compared to EG2 }(\sim 10 \% ; \sim 79.0 \text { vs. } \sim 71.5 ; p \\
<0.05) \\
\text { - EG1 increased NT at post compared to } \\
\text { pre, at SJFT1 }(\sim 8 \% ; \sim 27.1 \text { vs. } \sim 25.1 ; p< \\
0.001) \text {, SJFT2 }(\sim 8 \% ; \sim 26.1 \text { vs. } \sim 24.1 ; p< \\
0.001) \text {, and SJFT3 }(\sim 9 \% ; \sim 25.8 \text { vs. } \sim 23.7 ; p< \\
0.001) \\
\text { - Between-group (EG1 vs. EG2) differences } \\
\text { at post were found for NT at SJFT1 }(\sim 13 \% \text {; } \\
\sim 27.1 \text { vs. } \sim 24.0 ; p<0.05) \text { and SJFT3 }(\sim 10 \% \text {; } \\
\sim 25.8 \text { vs. } \sim 23.5 ; p<0.05) .\end{array}$ \\
\hline
\end{tabular}

CAFF: caffeine; EC: experimental condition; EG: experimental group; min: minutes; NT: number of throws; PLAC: placebo; RPE: rate of perceived exertion; SJFT: special judo fitness test; TNT: total number of throws;

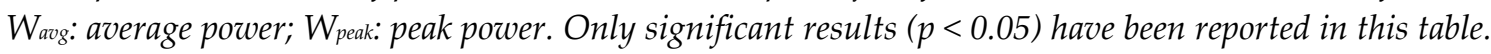




\begin{tabular}{|c|c|c|c|c|}
\hline \multicolumn{5}{|c|}{$\begin{array}{l}\text { Summary of significant results reported by studies evaluating the ergogenic effects of } \mathrm{NaHCO}_{3} \text {, } \\
\text { Creatine, and } \mathrm{HMB} \text { on performance in judo athletes. }\end{array}$} \\
\hline \multicolumn{5}{|c|}{$\mathrm{NaHCO}_{3}$} \\
\hline $\begin{array}{l}\text { Artioli et al. } \\
(2007)\left(1^{\text {st }}\right. \\
\text { protocol })\end{array}$ & $\begin{array}{l}\text { Judokas at } \\
\text { the national } \\
\text { and } \\
\text { internationa } \\
\text { l level }(\mathrm{n}=9)\end{array}$ & $\begin{array}{l}\text { EC1: } 300 \mathrm{mg} / \mathrm{kg} \mathrm{NaHCO}_{3} \\
\text { (120 min before testing) } \\
\text { EC2: PLAC }\end{array}$ & $3 \times$ SJFT & $\begin{array}{l}\text { EC1 increased TNT compared to EC2 }(5 \% ; 82.1 \\
\text { vs. } 78.1 ; p<0.01) \\
\text { EC1 increased TNT compared to EC2 at SJFT2 } \\
(6 \% ; 27.4 \text { vs. } 25.9 ; p<0.05) \text { and SJFT3 }(5 \% ; 27.0 \text { vs. } \\
25.6 ; p<0.05)\end{array}$ \\
\hline $\begin{array}{l}\text { Artioli et al. } \\
(2007)\left(2^{\text {nd }}\right. \\
\text { protocol })\end{array}$ & $\begin{array}{l}\text { Judokas at } \\
\text { the national } \\
\text { and } \\
\text { internationa } \\
1 \quad \text { level } \\
(\mathrm{n}=14)\end{array}$ & $\begin{array}{l}\text { EC1: } 300 \mathrm{mg} / \mathrm{kg} \mathrm{NaHCO}_{3} \\
\text { (120 before testing) } \\
\text { EC2: PLAC }\end{array}$ & $\begin{array}{l}4 \text { bouts of the } \\
\text { Wingate test for the } \\
\text { upper-limbs }\end{array}$ & $\begin{array}{l}\text { Wingate 3: EC1 increased } W_{\text {avg }} \text { compared to EC2 } \\
(\sim 10 \% ; \sim 3.4 \text { vs. } \sim 3.1 \mathrm{~W} / \mathrm{kg} ; p<0.05) \\
\text { Wingate } 4 \text { : EC1 increased } W_{\text {avg }} \text { compared to EC2 } \\
(\sim 14 \% ; \sim 3.3 \text { vs. } \sim 2.9 \mathrm{~W} / \mathrm{kg} ; p<0.05) \text {; EC1 increased } \\
W_{\text {peak }} \text { compared to EC2 }(\sim 14 \% ; \sim 5.1 \text { vs. } \sim 4.3 \mathrm{~W} / \mathrm{kg} \text {; } \\
p<0.05)\end{array}$ \\
\hline \multicolumn{5}{|c|}{ Creatine } \\
\hline $\begin{array}{l}\text { Sterkowicz } \\
\text { et al. (2012) }\end{array}$ & $\begin{array}{l}\text { Experienced } \\
\text { judokas } \\
(\mathrm{n}=10)\end{array}$ & $\begin{array}{l}6 \quad \text { weeks of } \\
\text { supplementation: } \\
\text { EC1: } 0.07 \mathrm{~g}^{*} \mathrm{~kg}^{*} \mathrm{LBM} / \text { day } \\
\text { creatine } \\
\text { EC2: PLAC }\end{array}$ & $\begin{array}{l}\text { Pre- and post- } \\
\text { supplementation: } \\
\text { - SJFT } \\
\text { - Modified Wingate } \\
\text { Test } \\
\text { - Graded exercise } \\
\text { test } \\
\text { - Body composition }\end{array}$ & $\begin{array}{l}\text { Modified Wingate Test: } \\
\text { Time to reach } W_{\text {peak: }} \text { CE1 decreased }(-7.8 \% ; 3.68 \pm \\
0.77 \text { vs. } 3.99 \pm 0.71 \mathrm{~s} ; p<0.05) \text { and CE2 decreased } \\
(-7.3 \% ; 3.42 \text { vs. } 3.69 \mathrm{~s} ; p<0.05) \\
\text { Fatigue index: CE1 post was lower, when } \\
\text { compared to CE2 post }(-15.8 \% ; 41.0 \pm 2.9 \text { vs. } 48.7 \\
\pm 5.1 ; p<0.05)\end{array}$ \\
\hline \multicolumn{5}{|c|}{ HMB } \\
\hline $\begin{array}{l}\text { Durkalec- } \\
\text { Michalski et } \\
\text { al. (2017) }\end{array}$ & $\begin{array}{l}\text { Experienced } \\
\text { judokas } \\
(\mathrm{n}=12), \\
\text { wrestlers } \\
(\mathrm{n}=13) \text {, and } \\
\text { Brazilian } \\
\text { jiu-jitsu } \\
\text { athletes } \\
(\mathrm{n}=17)\end{array}$ & $\begin{array}{l}12 \text { weeks of } \\
\text { supplementation with 10- } \\
\text { day washout period } \\
\text { between } \\
\text { supplementations: } \\
\text { EC1: } 3 \times 1 \mathrm{~g} / \text { day HMB } \\
\text { EC2: PLAC }\end{array}$ & $\begin{array}{l}\text { Pre- and post- } \\
\text { supplementatio } \\
\text { n: } \\
\text { - Wingate Test } \\
\text {-Incremental } \\
\text { progressive } \\
\text { cycle ergometer } \\
\text { test }\end{array}$ &  \\
\hline $\begin{array}{l}\text { Hung et al. } \\
\text { (2010) }\end{array}$ & $\begin{array}{l}\text { Female } \\
\text { judokas at } \\
\text { the national } \\
\text { and } \\
\text { internationa } \\
1 \text { level }(\mathrm{n}=8)\end{array}$ & $\begin{array}{l}\text { EC1: } 3 \times 1 \mathrm{~g} / \text { day HMB } \\
\text { EC2: PLAC }\end{array}$ & $\begin{array}{l}\text { - Body } \\
\text { composition } \\
\text { - Wingate Test } \\
\text { - Intermittent } \\
\text { grip test }(7 \text { sets } \\
\text { x } 30 \text { s hand all- } \\
\text { out grip + } 10 \mathrm{~s} \\
\text { recovery) }\end{array}$ & $\begin{array}{l}\text { Body composition: } \\
\text { - EC1 significantly decreased body weight }(-1.8 \% \text {; } \\
57.3 \pm 2.4 \text { vs. } 56.2 \pm 2.2 \mathrm{~kg}) \text { and } \% \mathrm{FM}(-4.2 \% ; 20.2 \pm \\
2.1 \text { vs. } 19.4 \pm 1.9 \%) \text { at post-test, compared with pre- } \\
\text { test }\end{array}$ \\
\hline \multicolumn{5}{|c|}{ 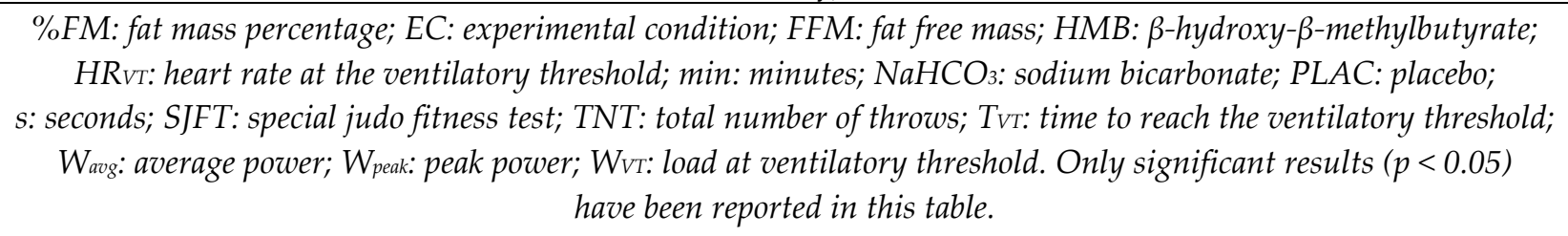 } \\
\hline
\end{tabular}


Table 1c

Summary of significant results reported by studies evaluating the ergogenic effects of combined Caffeine $+\mathrm{NaHCO}_{3}$, and combined $\beta$-alanine $+\mathrm{NaHCO}_{3}$ on performance in judo athletes.

\begin{tabular}{|c|c|c|c|c|}
\hline \multicolumn{5}{|c|}{ Caffeine $+\mathrm{NaHCO}_{3}$} \\
\hline $\begin{array}{l}\text { Felippe et } \\
\text { al. (2016) }\end{array}$ & $\begin{array}{l}\text { Experienced } \\
\text { male judokas } \\
\text { at the regional } \\
\text { and national } \\
\text { level }(\mathrm{n}=10)\end{array}$ & $\begin{array}{l}\mathrm{EC} 1: 6 \mathrm{mg} / \mathrm{kg} \text { CAFF } \\
(60 \mathrm{~min} \text { before } \\
\text { testing) } \\
\mathrm{EC} 2: 3 \times 100 \mathrm{mg} / \mathrm{kg} \\
\mathrm{NaHCO}_{3}(120,90, \text { and } \\
60 \mathrm{~min} \text { before testing) } \\
\mathrm{EC} 3: 3 \times 100 \mathrm{mg} / \mathrm{kg} \\
\mathrm{NaHCO} \text { (120, } 90 \text {, and } \\
60 \mathrm{~min} \text { before testing) } \\
+6 \mathrm{mg} / \mathrm{kg} \text { CAFF (60 } \\
\text { min before testing) } \\
\text { EC4: PLAC }\end{array}$ & $-3 \times$ SJFT & $\begin{array}{l}\text { Total throws: } \\
\text { - EC3 showed higher TNT than EC4 }(5.66 \% \text {; } \\
72.7 \pm 3.1 \text { vs. } 68.8 \pm 4.2 ; p<0.01) \\
\text { Throws at SJFT1: } \\
\text { - larger number of throws for EC3 compare } \\
\text { to EC4 }(5.17 \% ; 24.4 \pm 1.5 \text { vs. } 23.2 \pm 1.5 ; p< \\
0.05) \\
\text { Throws at SJFT3: } \\
\text { - larger number of throws for EC3, } \\
\text { compared to EC4 ( } 8.44 \% ; 24.4 \pm 1.0 \text { vs. } 22.5 \pm \\
1.6 ; p<0.01) \\
-\quad \text { larger number of throws for EC2, } \\
\text { compared to EC4 }(5.33 \% ; 23.7 \pm 1.1 \text { vs. } 22.5 \pm \\
1.6 ; p<0.05)\end{array}$ \\
\hline \multicolumn{5}{|c|}{$\beta$-alanine + $\mathrm{NaHCO}_{3}$} \\
\hline $\begin{array}{l}\text { Tobias et al. } \\
\text { (2013) }\end{array}$ & $\begin{array}{l}\text { Well-trained } \\
\text { and } \\
\text { experienced } \\
\text { judokas }(n=16) \\
\text { and Brazilian } \\
\text { jiu-jitsu }(n=21) \\
\text { athletes }\end{array}$ & 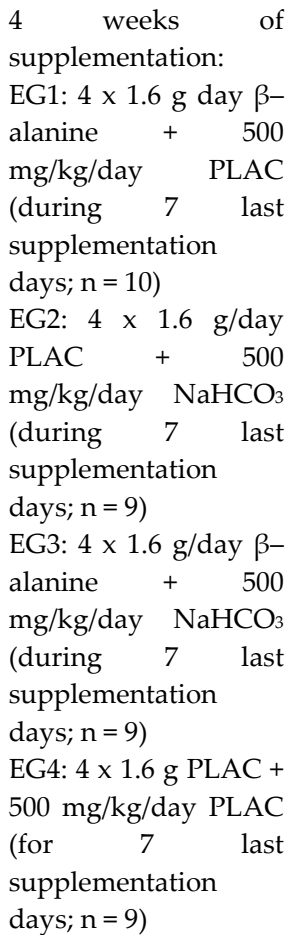 & $\begin{array}{l}4 \quad x \quad 30 \quad s \\
\text { Wingate Test } \\
\text { for the } \\
\text { upper-body } \\
\text { (pre- and } \\
\text { post- } \\
\text { supplementat } \\
\text { ion) }\end{array}$ & 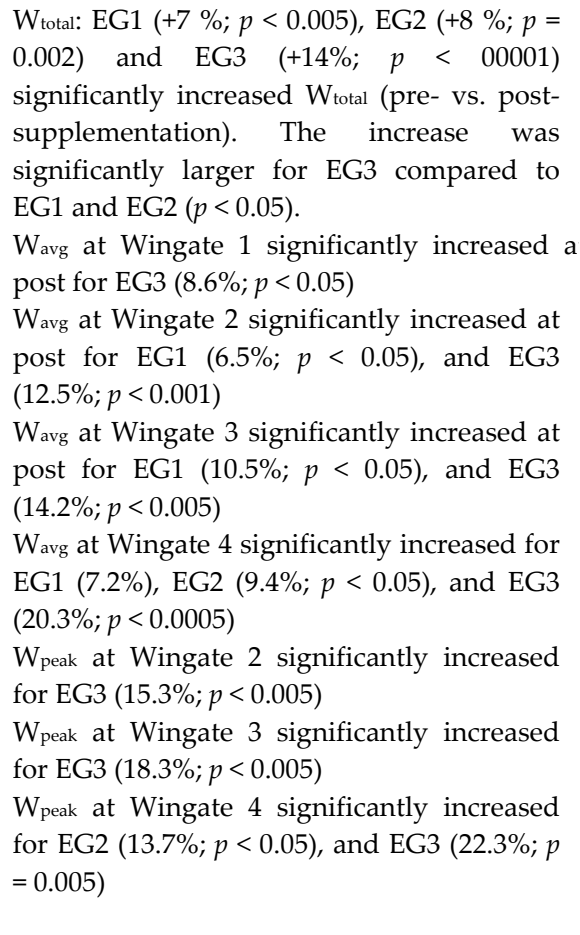 \\
\hline
\end{tabular}

CAFF: caffeine; EC: experimental condition; EG: experimental group; min: minutes; s: seconds; $\mathrm{NaHCO}_{3}$ : sodium bicarbonate; PLAC: placebo; SJFT: special judo fitness test; TNT: total number of throws; $W_{\text {avg: }}$ average power; $W_{\text {peak: }}$ peak power; $W_{\text {total: }}$ total work. Only significant results $(p<0.05)$ have been reported in this table. 


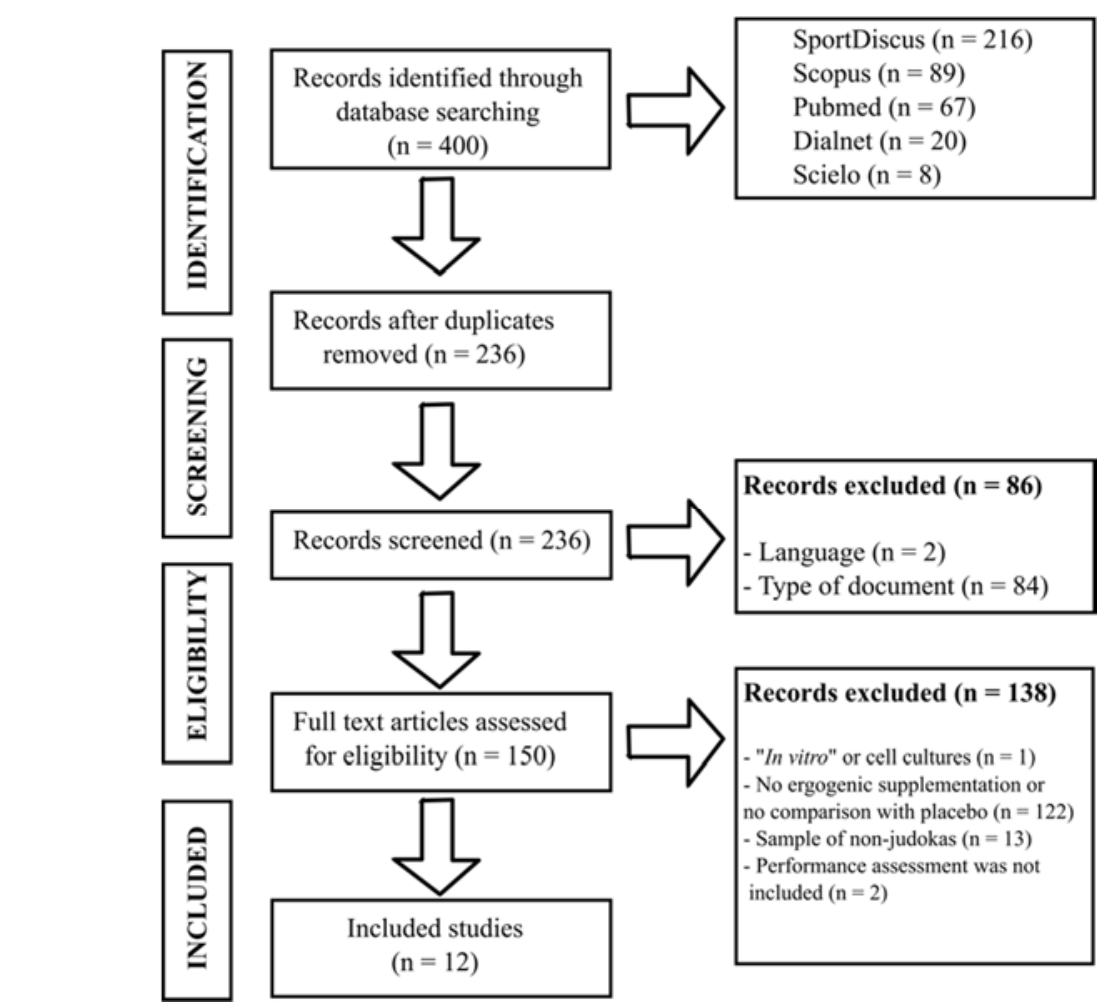

Figure 1

Flow diagram of the article selection process.

A total of 130 judokas were recruited in the 11 articles included in this review. In addition to judokas, one article also tested Brazilian jiujitsu athletes (Tobias et al., 2013), whereas in the second article wrestlers and Brazilian jiu-jitsu athletes were also evaluated (Durkalec-Michalski et al., 2017). In ten studies, adult judokas were evaluated ( $\mathrm{n}=112$ ) (Artioli et al., 2007; de Andrade Kratz et al., 2017; Durkalec-Michalski et al., 2017; Felippe et al., 2016; Hung et al., 2010; Lopes-Silva et al., 2014; Souissi et al., 2012, 2015;
Sterkowicz et al., 2012; Tobias et al., 2013), whereas one article evaluated teen-athletes $(\mathrm{n}=$ 18) (Astley et al., 2017).

The nutritional supplements examined in judokas were caffeine, $\beta$-hydroxy- $\beta$ methylbutyrate (HMB), $\beta$-alanine $(\mathrm{BA})$, sodium bicarbonate $\left(\mathrm{NaHCO}_{3}\right)$ and creatine. A total of 4 articles analyzed the effects of caffeine on judo performance (Astley et al., 2017; Lopes-Silva et al., 2014; Souissi et al., 2012, 2015); two studies evaluated the effects of $\beta$-hydroxy- $\beta$ - 
methylbutyrate (HMB) (Durkalec-Michalski et al., 2017; Hung et al., 2010); and one study examined the effects of $\beta$-alanine (de Andrade Kratz et al., 2017), $\mathrm{NaHCO}_{3}$ (Artioli et al., 2007) and creatine (Sterkowicz et al., 2012). Besides, two studies examined the potential additive effect of two supplements: $\beta$-alanine with $\mathrm{NaHCO}_{3}$ (Tobias et al., 2013), and caffeine with $\mathrm{NaHCO}_{3}$ (Felippe et al., 2016).

Regarding the indirect judo-related performance test utilized, the $30 \mathrm{~s}$ all-out sprint test (Wingate test) was applied in seven studies (Artioli et al., 2007; Durkalec-Michalski et al., 2017; Hung et al., 2010; Souissi et al., 2012, 2015; Sterkowicz et al., 2012; Tobias et al., 2013): in five studies participants were asked to perform this test with the lower-limbs (Durkalec-Michalski et al., 2017; Hung et al., 2010; Souissi et al., 2012, 2015; Sterkowicz et al., 2012), whereas in two studies this test was performed with the upperlimbs (Artioli et al., 2007; Tobias et al., 2013).

Furthermore, in six articles participants underwent tests directly related with judo performance, such the Special Judo Fitness Test (SJFT) (Artioli et al., 2007; Astley et al., 2017; de Andrade Kratz et al., 2017; Felippe et al., 2016; Lopes-Silva et al., 2014; Sterkowicz et al., 2012). In two of these studies, participants performed only one set of the SJFT (Astley et al., 2017; Sterkowicz et al., 2012), while the remaining four studies performed 3 sets of the SJFT (Artioli et al., 2007; de Andrade Kratz et al., 2017; Felippe et al., 2016; Lopes-Silva et al., 2014). Additionally, simple reaction times (Souissi et al., 2012, 2015), and aerobic capacity (Durkalec-Michalski et al., 2017) were also evaluated. Finally, three studies evaluated the effect of a long-term supplementation protocol on athletes' body composition (Durkalec-Michalski et al., 2017; Hung et al., 2010; Sterkowicz et al., 2012).

Table 1 (a, b, c) summarizes sample characteristics, supplementation protocols, performance tests and the main results of the above-mentioned studies. Only results revealing significant differences $(p<0.05)$ are reported.

\section{Discussion}

\section{Effects of caffeine supplementation}

Caffeine (1,3,7 trimethylxanthine) is metabolized by the liver and, through enzymatic actions, results in three metabolites: paraxanthine, theophylline, and theobromine. Caffeine is rapidly absorbed by the body, and appears in the blood within 5-15 minutes, reaching a peak between 45 and 60 minutes after ingestion (McLellan et al., 2016). Caffeine is a molecule similar to adenosine and competes with it, joining adenosine A1, A2a and A2b receptors (AboSalem, 2003), which makes it an important modulator of the central nervous system activity, inhibiting the activity of the parasympathetic nervous system. As adenosine increases drowsiness and pain perception in the central nervous system, caffeine supplementation may prevent such effects (Fredholm et al., 1994), leading to increased cognitive performance and alertness, as well as to a reduction in the subjective rate of perceived exertion (RPE) (Doherty and Smith, 2005).

At the metabolic level, caffeine increases the amount of plasma catecholamines (MoraRodriguez et al., 2012), stimulating glycolytic activity (Simmonds et al., 2010), due to its antagonistic action on adenosine, which blunts the inhibitory action of phosphofructokinase under acidosis conditions (Simmonds et al., 2010). In addition, in response to exercise, caffeine supplementation increases circulating testosterone levels (Beaven et al., 2008), while within the skeletal muscle, caffeine maintains electrolyte homeostasis (Kalmar, 2005), improving the $\mathrm{Na}^{+} / \mathrm{K}^{+}$pump activity (Mohr et al., 2011), and promoting calcium release from the sarcoplasmic reticulum (Simmonds et al., 2010). Furthermore, caffeine ingestion has been shown to increase neuromuscular activity (Kalmar, 2005), improving intra- and inter-muscular coordination (Del Coso et al., 2012). This enhanced neuromuscular activity pattern is revealed by an improved agility and decision making performance (van Duinen et al., 2005), as well as by an increased performance in high-intensity actions involving velocity (Del Coso et al., 2012; Pallarés et al., 2013), coordination and accuracy (Foskett et al., 2009), muscle strength (Goldstein et al., 2010) or muscle power (Del Coso et al., 2012; Pallarés et al., 2013).

Four studies have evaluated the effects of caffeine supplementation on judo performance (Astley et al., 2017; Lopes-Silva et al., 2014; Souissi et al., 2012, 2015). Lopes-Silva et al. (2014) recruited six high-level judokas who were provided with $6 \mathrm{mg} / \mathrm{kg}$ of caffeine before 
executing 3 sets of the SJTF. No differences were found in the SJTF test results. However, the RPE and blood lactate levels were reduced in response to caffeine ingestion (Lopes-Silva et al., 2014). In contrast, Astley et al. (2017) observed that ingestion of $4 \mathrm{mg} / \mathrm{kg}$ of caffeine $1 \mathrm{~h}$ before the SJFT increased the number of takedowns (by 31\%) and the SJFT index (variable that relates the heart rate with the total number of throws carried out during the test) in 18 judokas competing at the national level. The small size $(n=6)$ and the heterogeneity (4 different weight categories) of the sample recruited by Lopes-Silva et al. (2014) may explain the observed differences.

The remaining two investigations evaluated the effect of caffeine supplementation (5 $\mathrm{mg} / \mathrm{kg}$ ) on Wingate test performance (Souissi et al., 2012, 2015), which is commonly used to assess glycolytic capacity (Davis and Green, 2009). In the first of the two investigations, caffeine intake improved reaction time (by 13\%), although no effect on peak or mean power output was found in the Wingate test (Souissi et al., 2012). Some years later, Souissi et al. (2015) reported a similar improvement in reaction time (by $12 \%$ ), along with increased peak $(8 \%)$ and mean $(7 \%)$ power output in the Wingate test.

Regarding the improvements found for reaction time, they may have their origin in the reduction of drowsiness (Fredholm et al., 1994), and the enhancement of attention and mood following supplementation (Ruijter et al., 2000), as well as potential improvements in synaptic transmission (Latini and Pedata, 2001). Differences found for the Wingate test could be attributed to the effects of circadian rhythms. In this way, it has been proven that circadian rhythms affect different physiological variables that make physical performance in the early hours of the morning diminishing compared to that performed in the afternoon (Lopez-Samanes et al., 2017). Thus, in the Wingate test, lower values have been reported in the morning, and higher at noon (Souissi et al., 2013). Therefore, it is possible that caffeine supplementation has a potential higher ergogenic effect when the exercise takes place in the morning, due to the lower performance that occurs as a result of circadian rhythms effect.

Despite caffeine supplementation having a superior effect when the effort is accomplished in the morning (Souissi et al., 2015), the reduction of reaction time (Souissi et al., 2012, 2015) and the RPE (Astley et al., 2017; Lopes-Silva et al., 2014; Souissi et al., 2012, 2015) observed following caffeine ingestion, combined with its potential benefits for the glycolytic capacity measured via a judo non-specific test, such as the Wingate test (Souissi et al., 2015) or a judo specific test, such as the SJFT (Astley et al., 2017) indicate the intake of about $6 \mathrm{mg} / \mathrm{kg}$ of caffeine 60 minutes prior to a fight (López-González et al., 2018) in order to match the exerted effort with the moment at which maximum plasma concentration takes place (McLellan et al., 2016).

\section{Effects of $\beta$-alanine supplementation}

$\beta$-alanine (BA) is an amino acid synthesized in the liver, from the degradation of thymine, cytosine and uracil that can be ingested through diet from different sources (i.e., animal or supplements). BA is found in skeletal muscle in combination with L-histidine forming the dipeptide carnosine, a protein with neurotransmitter (Caruso et al., 2012) and antioxidant functions (Boldyrev, 2012). Nonetheless, BA most important functions are related to the regulation of the acid-base balance (Harris et al., 2006), showing intracellular buffering capacity, and facilitating calcium sensitivity in muscle fibers (Dutka and Lamb, 2004), which improves excitation-contraction processes in this tissue (Begum et al., 2005).

Supplementation with BA has been shown to increase muscle carnosine reserves, whereas no effects were observed after L-histidine ingestion (Blancquaert et al., 2017). Since dietary intake of $\mathrm{BA}$ is the limiting factor of muscle carnosine synthesis (Stellingwerff et al., 2012), prolonged BA supplementation could increase muscle carnosine levels by $40-80 \%$ (Harris et al., 2006). Carnosine acts as a calcium transporter to the sarcoplasm (Dutka and Lamb, 2004), which is essential to facilitate cross-bridges formatting in muscle fibers, and it also captures $\mathrm{H}^{+}$ions in the sarcolemma (Swietach et al., 2013), regulating intracellular acid-base balance. Consequently, increased carnosine levels improve muscle contraction strength through an increase in the bioavailability of calcium in the sarcoplasm, while the release of $\mathrm{H}^{+}$delays the inhibition of phosphofructokinase (PFK) and thereby preserves the activity of the glycolytic and phosphagens 
energy systems.

A recent meta-analysis has reported that BA supplementation improves performance in efforts that last between 1 and 4 minutes (Saunders et al., 2017), where a high accumulation of $\mathrm{H}^{+}$occurs as the result of elevated glycolytic activity. In addition, it has been suggested that supplementation with BA involves the inhibition of the enzyme phosphofructokinase (Domínguez et al., 2015), affecting the system of high-energy phosphagens and glycolysis. At the psychological level, there is evidence of a significant increase in the subjective perception of effort following BA supplementation (Price and Moss, 2007). Therefore, all these effects will show an impact of muscle contraction in situations of acidosis (Fabiato and Fabiato, 1978), which results in a decreased electromyographic activity (Taylor et al., 1997).

Decreased levels of intracellular $\mathrm{pH}$ levels have been reported during judo combats, and they are believed to be a critical cause of combat loss (Franchini et al., 2011). BA may have an ergogenic effect in this sport due to its highintensity and intermittent characteristics. For this reason, an investigation aimed at verifying the effects of BA ingestion ( $6.4 \mathrm{~g} /$ day) during 4 weeks on 3 consecutive SJFT results in a group of 23 judokas at the national and international level (de Andrade Kratz et al., 2017). In that investigation, judokas who were supplemented with BA increased the total number of throws compared with a placebo condition. This result is in line with previous evidence suggesting that BA improves strength and power levels in athletes performing exercises with a high glycolytic component (Maté-Muñoz et al., 2017).

Of note, due to the fact that side effects of BA supplementation include the appearance of paresthesia, in a dose-response manner (Harris et al., 2006), it has been proposed to divide the dose considered ergogenic (4.8-6.4 g/day) into 4-8 smaller portions of 0.8-1.6 g/day (Domínguez et al., 2015; Maughan et al., 2018; Saunders et al., 2017).

\section{Effects of $\mathrm{NaHCO}_{3}$ supplementation}

$\mathrm{NaHCO}_{3}$ is the main regulator of the acidbase balance. Since the sarcolemma is not permeable to $\mathrm{NaHCO}_{3}$, supplementation with $\mathrm{NaHCO}_{3}$ boosts plasma levels, which increases the gradient concentration between muscle fiber and blood, facilitating the $\mathrm{H}^{+}$flow (Lancha Junior et al., 2015). This regulates intramuscular $\mathrm{pH}$, allowing a greater use of the glycolytic pathway and delaying the onset of fatigue (Granier et al., 1996).

Similar to $\beta$-alanine, supplementation with $\mathrm{NaHCO}_{3}$ has shown an ergogenic effect in response to high-intensity intermittent efforts, in which decreased $\mathrm{pH}$ levels constitute a performance limiting factor (Siegler et al., 2016), since it allows a higher utilization of the glycolytic pathway until reaching critical $\mathrm{pH}$ levels that affect the activity of phosphofructokinase (PFK).

In order to verify the effects of $\mathrm{NaHCO}_{3}$ supplementation on judo performance, Artioli et al. (2007) conducted a study in which a sample of well-trained judokas performed a test consisting of 4 sets of the Wingate arms crank test or a test consisting of 3 sets of the SJFT, either under a placebo condition or supplemented with $\mathrm{NaHCO}_{3}$ (300 mg/kg). Authors chose to use an arm crank ergometer for this investigation based on the fact that exercises involving the upper-limbs give rise to a greater increase in $\mathrm{H}^{+}$concentrations compared to those involving the lower limbs (Robertson et al., 1987). In this research, supplementation presented an ergogenic effect, increasing the average power in the third and fourth Wingate test performance, as well as the peak power output in the last sprint (Artioli et al., 2007). Regarding the effects on performance directly related to judo, it was found that supplementation with $300 \mathrm{mg} / \mathrm{kg}$ of $\mathrm{NaHCO}_{3} 120$ minutes before three consecutive SJFTs increased the number of takedowns in the second and third sets. Given that the effects of $\mathrm{NaHCO}_{3}$ on sprint and SJFT performance have been detected after several repetitions of this exhausting exercises $\left(4^{\text {th }}\right.$ sprint and $3^{\text {rd }}$ SJFT performance), it can be argued that the main ergogenic effect of this supplement occurs under fatiguing conditions (Artioli et al., 2007), potentially due to the buffering capacity of $\mathrm{NaHCO}_{3}$

Nonetheless, $\mathrm{NaHCO}_{3}$ supplementation has also caused ergogenic effects in response to a single Wingate test after higher doses $(500 \mathrm{mg} / \mathrm{kg})$ (Douroudos et al., 2006). For this reason, although results reported by Artioli et al. (2007) suggest that supplementation with $\mathrm{NaHCO}_{3}$ at a dose of $300 \mathrm{mg} / \mathrm{kg}$ could be considered an ergogenic practice in judokas who will face several combats 
in the same day, the superior effect found at doses of $500 \mathrm{mg} / \mathrm{kg}$ in response to a single all-out sprint exercise cannot be neglected (Douroudos et al., 2006). Therefore, $\mathrm{NaHCO}_{3}$ doses may vary depending on judokas' needs during competition. Finally, $\mathrm{NaHCO}_{3}$ is known to cause some side effects, mainly gastrointestinal discomfort, which may be avoided by sparing it in smaller doses, coingesting it with carbohydrate, or using sodium citrate as an alternative (Maughan et al., 2018).

\section{Creatine}

Creatine supplementation is a common practice among combat sport athletes (Kreider et al., 2017). Creatine is a combination of nonessential amino acids (arginine, glycine and methionine), and is mainly produced endogenously in the liver and kidney. It has been suggested that creatine daily requirements are 2 g/day in healthy individuals (Cooper et al., 2012).

Several functions have been attributed to creatine supplementation, such as ATP resynthesis promotion (Volek and Kraemer, 1996), intracellular acid-base balance regulation (Quinn et al., 1992), biological membranes' stabilization and muscle protein synthesis stimulation (Persky and Brazeau, 2001).

In judo, high-intensity actions last 15-30 s, which is enough time to stimulate a complete depletion of PCr. Given that rest intervals between judo actions (10-15 s) do not allow the full restoration of $\mathrm{PCr}$ and ATP reserves (Franchini et al., 2013), creatine could exert its ergogenic effects in judokas by preserving muscle ATP availability. Nonetheless, the potential positive impact of creatine in judo performance has only been analyzed in one study (Sterkowicz et al., 2012). Sterkowicz et al. (2012) tested a group of 10 experienced judo athletes, who were provided with $5 \mathrm{~g} /$ day of creatine for 6 weeks. Results showed that, compared to the placebo condition, the treatment group increased peak power output ( $\left.\mathrm{W}_{\text {peak }}\right)$ and decreased the time to reach $\mathrm{W}_{\text {peak }}$ (by $7.8 \%$ ) in a 30 -s all-out sprint test (Wingate), supporting the role of creatine in ATP reserves' preservation during high-intensity exercise. However, this effect was not observed in response to the special judo fitness test. Thus, more research is needed in order to examine the potential ergogenic effect of creatine supplementation on judo performance by promoting ATP recycling.
Furthermore, body composition remodeling can be another attractive outcome of nutritional supplementation for judo athletes. Given that creatine ingestion seems to promote increased lean body mass in judo athletes (Sterkowicz et al., 2012), as it was previously shown in response to resistance training (Chilibeck et al., 2017), this potential effect should also be considered in future research.

\section{$\beta$-Hydroxy $\beta$-methylbutyric acid (HMB)}

The $\beta$-Hydroxy $\beta$-methylbutyric acid $(\mathrm{HMB})$ is a leucine metabolite derived from this essential amino acid transamination to $\alpha$ ketoisocaproic acid $(\alpha$-KIC), which is subsequently converted into HMB by dioxygenases (Durkalec-Michalski and Jeszka, 2015).

Increases in cholesterol, acetyl Co-A and anabolic hormones production (i.e., GH or IGF-1) (Durkalec-Michalski and Jeszka, 2015) are some of the beneficial effects related to HMB ingestion. In this regard, HMB stimulates mTOR signaling pathways, but this activation is lower than the one observed after leucine ingestion (Wilkinson et al., 2013) and, more importantly, it only takes place under some catabolic conditions (Eley et al., 2008). Therefore, the effect of HMB on protein synthesis seems to be restricted to some anti-catabolic stimuli by which HMB may blunt protein degradation through anti-apoptotic signaling via the ubiquitin-proteasome pathway (Smith et al., 2004), promoting myogenic proliferation, differentiation and survival (Kornasio et al., 2009). Considering the controversy about the anabolic role of HMB (Teixeira et al., 2018), its anticatabolic effect seems to be out of debate.

Judo athletes are commonly involved in weight loss programs that may affect muscle mass and performance; consequently, it is of great importance to elaborate nutritional strategies focused on muscle capacity and preservation of muscle mass. In this regard, Hung et al. (2010) examined the effect of $3 \mathrm{~g} /$ day of $\mathrm{HMB}$ supplementation during 3 days in female judo athletes who followed a hypocaloric diet, reporting a decrease in fat mass, which coincided with an increase in total cholesterol, blood urea nitrogen and uric acid. In contrast, muscle mass and sprint performance (Wingate test) remained unchanged.

Interestingly, Durkalec-Michalski et al. 
(2017) evaluated the effects of the same dose of HMB ( $3 \mathrm{~g}$ /day) supplemented during 12 weeks on body composition, reporting not only a reduction in fat mass, but also an increase in lean body mass even when athletes consumed a "normal" diet $(\sim 3100 \mathrm{kcal} /$ day $)$. Besides, the improvement in body composition remodeling was accompanied by an enhancement in 30-s all-out Wingate test performance, finding an improved time to reach the ventilatory threshold, threshold load, $W_{\text {peak, }}$ and tolerance to lactate accumulation (DurkalecMichalski et al., 2017).

Overall, HMB supplementation may preserve skeletal muscle mass in combat sports, mainly under some catabolic conditions, but also seems to increase high-intensity exercise performance, which is essential in judo competition, since several combats take place during the same day (Durkalec-Michalski et al., 2016).

\section{Ergogenic effects of combined supplementation}

There is high prevalence of sport supplements use among athletes. Interestingly, most of these athletes consume several types of supplements at the same time, despite the interaction effects of the majority of these supplements are not fully understood (Burke, 2017).

In judo, only two studies have evaluated the combined effects of different supplements (Felippe et al., 2016; Tobias et al., 2013). Due to the high glycolytic demands of combat sports (Artioli et al., 2010b), muscle pH buffering capacity plays a critical role to preserve performance in judo (Artioli et al., 2010a). In this regard, the buffering capacity of $\mathrm{NaHCO}_{3}$ has been evaluated in conjunction with caffeine (Felippe et al., 2016) and $\beta$-Alanine (Tobias et al., 2013).

Tobias et al. (2013) asked judo and jiujitsu athletes to ingest $6.4 \mathrm{~g} /$ day of BA for 4 weeks, plus $500 \mathrm{mg} / \mathrm{kg} /$ day of $\mathrm{NaHCO}_{3}$ during the last week. Athletes performed four 30-s upper-body Wingate tests $(3 \mathrm{~min}$ rest intervals between sprints) before and after the treatment. Authors observed an additive effect of $\mathrm{BA}$ plus $\mathrm{NaHCO}_{3}$ supplementation in the total work done, as well as increased mean power output and a reduced rate of perceived exertion (Tobias et al., 2013).

Similarly, the $\mathrm{NaHCO}_{3}$ ergogenic effect has been analyzed in combination with caffeine supplementation (Felippe et al., 2016). Given the explosive characteristics of judo actions, caffeine has revealed to be an effective supplement in this sport (Astley et al., 2017; Souissi et al., 2015). Thus, Felippe et al. (2016) aimed at determining the combined effects of the buffering capacity of $\mathrm{NaHCO}_{3}(300 \mathrm{mg} / \mathrm{kg}$ of body mass) plus the boosting capacity of caffeine $(6 \mathrm{mg} / \mathrm{kg}$ of body mass). They asked participants to perform 3 consecutive SJFTs interspersed with $5 \mathrm{~min}$ rest intervals. The combination of $\mathrm{NaHCO}_{3}$ and caffeine resulted in increased performance (total number of throws), particularly in the first and fourth SJFT tests, and larger concentrations of circulating lactate (Felippe et al., 2016).

Therefore, $\mathrm{NaHCO}_{3}$ ingestion in conjunction with BA or caffeine promotes an additional ergogenic effect that seems to imply a higher stimulation of glycolysis, which leads to improved specific and general performance in judo athletes.

\section{Conclusions}

Evidence reviewed in this study suggests that dietary supplementation may improve judorelated performance. Based on the current evidence, it can be concluded that:

- Supplementation with 5-6 mg/kg of caffeine leads to reduction of reaction time and the RPE during judo combat simulations, as well as to improved judo-related performance measures (i.e.: number of throws, peak power, and mean power). Moreover, there is evidence suggesting that morning caffeine ingestion leads to larger judo-related performance improvements, when compared to the effects of caffeine ingested in the afternoon.

- Supplementation with $6.4 \mathrm{~g} /$ day of $\beta$-alanine has been reported to exert an ergogenic effect on judo-related performance, probably due to its indirect effects on muscle contraction. $\beta$-alanine supplementation is associated with increased muscle carnosine reserves, which facilitates cross-bridge formation in muscle fibers, and regulates intracellular acid-base balance, leading to improved muscular strength.

- Supplementation with $300-500 \mathrm{mg} / \mathrm{kg}$ of $\mathrm{NaHCO}_{3}$ has been shown to increase judorelated performance by boosting blood $\mathrm{pH}$ levels, which stimulates $\mathrm{H}^{+}$ diffusion to the extracellular space, and thus 
leads to a greater use of the glycolytic pathway. In order to avoid gastrointestinal discomfort associated with $\mathrm{NaHCO}_{3}$ supplementation, it is recommended to be ingested in small doses, co-ingested with carbohydrate or to use sodium citrate as an alternative.

- Positive effects on judo-related performance have been reported for HMB supplementation of $3 \mathrm{~g} /$ day. Chronic (12 weeks) HMB supplementation leads to improved body composition, along with increased cardiorespiratory performance, and greater performance of high-intensity exercises.
- Evidence suggests that supplementation with 3-5 g/day of creatine may have a positive effect on body composition, along with an effect on maximum power, and time to maximum power during performance of high-intensity efforts.

- Combined supplementation with $\mathrm{NaHCO}_{3}$ and caffeine, as well as $\mathrm{NaHCO}_{3}$ and $\beta$ alanine has been reported to have an additional ergogenic effect on body composition and high intensity performance.

\section{References}

Abo-Salem OM. Antinociceptive Effects of Novel A2B Adenosine Receptor Antagonists. J Pharmacol Exp Ther, 2003; 308(1): 358-366

Artioli GG, Gualano B, Coelho DF, Benatti FB, Gailey AW, Lancha AH. Does sodium-bicarbonate ingestion improve simulated judo performance? Int J Sport Nutr Exerc Metab, 2007; 17(2): 206-217

Artioli GG, Gualano B, Franchini E, Scagliusi FB, Takesian M, Fuchs M, Lancha AH. Prevalence, magnitude, and methods of rapid weight loss among judo competitors. Med Sci Sports Exerc, 2010a; 42(3): 436-442

Artioli GG, Iglesias RT, Franchini E, Gualano B, Kashiwagura DB, Solis MY, Benatti FB, Fuchs M, Junior AHL. Rapid weight loss followed by recovery time does not affect judo-related performance. J Sports Sci, 2010b; 28(1): 21-32

Astley C, Souza D, Polito M. Acute Caffeine Ingestion on Performance in Young Judo Athletes. Ped Exerc Sci, 2017; 29(3): 336-340

Beaven CM, Hopkins WG, Hansen KT, Wood MR, Cronin JB, Lowe TE. Dose effect of caffeine on testosterone and cortisol responses to resistance exercise. Int J Sport Nutr Exerc Metab, 2008; 18(2): 131141

Begum G, Cunliffe A, Leveritt M. Physiological role of carnosine in contracting muscle. Int J Sport Nutr Exerc Metab, 2005; 15(5): 493-514

Blancquaert L, Everaert I, Missinne M, Baguet A, Stegen S, Volkaert A, Petrovic M, Vervaet C, Achten E, De Maeyer M, De Henauw S, Derave W. Effects of Histidine and $\beta$-alanine Supplementation on Human Muscle Carnosine Storage. Med Sci Sports Exerc, 2017; 49(3): 602-609

Boldyrev AA. Carnosine: New concept for the function of an old molecule. Biochemistry (Mosc.), 2012; 77(4): 313-326

Burke LM. Practical Issues in Evidence-Based Use of Performance Supplements: Supplement Interactions, Repeated Use and Individual Responses. Sports Med, 2017; 47(Suppl 1): 79-100

Caruso J, Charles J, Unruh K, Giebel R, Learmonth L, Potter W. Ergogenic effects of $\beta$-alanine and carnosine: Proposed future research to quantify their efficacy. Nutrients, 2012; 4(7): 585-601

Casals C, Huertas JR, Franchini E, Sterkowicz-Przybycień K, Sterkowicz S, Gutiérrez-García C, EscobarMolina R. Special judo fitness test level and anthropometric profile of elite Spanish Judo athletes. $J$ Strength Cond Res, 2017; 31(5): 1229-1235

Chilibeck P, Kaviani M, Candow D, Zello GA. Effect of creatine supplementation during resistance training on lean tissue mass and muscular strength in older adults: a meta-analysis. Open Access J Sports Med, 2017; 8: 213-226 
Cooper R, Naclerio F, Allgrove J, Jimenez A. Creatine supplementation with specific view to exercise/sports performance: An update. J Int Soc Sports Nutr, 2012; 9(1): 33

Davis JK, Green JM. Caffeine and anaerobic performance: Ergogenic value and mechanisms of action. Sports Med, 2009; 39(10): 813-832

de Andrade Kratz C, de Salles Painelli V, de Andrade Nemezio KM, da Silva RP, Franchini E, Zagatto AM, Gualano B, Artioli GG. Beta-alanine supplementation enhances judo-related performance in highlytrained athletes. J Sci Med Sport, 2017; 20(4): 403-408

Del Coso J, Salinero JJ, González-Millán C, Abián-Vicén J, Pérez-González B. Dose response effects of a caffeine-containing energy drink on muscle performance: A repeated measures design. J Int Soc Sports Nutr, 2012; 9(1): 21

Doherty M, Smith PM. Effects of caffeine ingestion on rating of perceived exertion during and after exercise: A meta-analysis. Scand J Med Sci Sports, 2005; 15(2): 69-78

Domínguez R, Lougedo JH, Maté-Muñoz JL, Garnacho-Castaño MV. Effects of ß-alanine supplementation on athletic performance. Nutr Hosp, 2015; 31(1): 155-169

Douroudos II, Fatouros IG, Gourgoulis V, Jamurtas AZ, Tsitsios T, Hatzinikolaou A, Margonis K, Mavromatidis K, Taxildaris K. Dose-related effects of prolonged NaHCO3 ingestion during highintensity exercise. Med Sci Sports Exerc, 2006; 38(10): 1746-1753

Durkalec-Michalski K, Jeszka J. The efficacy of a $\beta$-hydroxy- $\beta$-methylbutyrate supplementation on physical capacity, body composition and biochemical markers in elite rowers: A randomised, double-blind, placebocontrolled crossover study. J Int Soci Sports Nutr, 2015; 12(1): 31

Durkalec-Michalski K, Jeszka J, Podgórski T. The effect of a 12-week beta-hydroxy-beta-methylbutyrate (HMB) supplementation on highly-trained combat sports athletes: A randomised, double-blind, placebo-controlled crossover study. Nutrients, 2017; 9(7)

Durkalec-Michalski K, Podgórski T, Sokołowski M, Jeszka J. Relationship between body composition indicators and physical capacity of the combat sports athletes. Arch Budo, 2016; 12: 247-256

Dutka TL, Lamb GD. Effect of carnosine on excitation-contraction coupling in mechanically-skinned rat skeletal muscle. J Muscle Res Cell Motil, 2004; 25(3): 203-213

Eley HL, Russell ST, Tisdale MJ. Attenuation of depression of muscle protein synthesis induced by lipopolysaccharide, tumor necrosis factor, and angiotensin II by $\beta$-hydroxy- $\beta$-methylbutyrate. AJP Endocrinol Metab, 2008; 295(6): 1409-1416

Fabiato A, Fabiato F. Effects of $\mathrm{pH}$ on the myofilaments and the sarcoplasmic reticulum of skinned cells from cardiace and skeletal muscles. J Physiol, 1978; 276: 233-255

Felippe LC, Lopes-Silva JP, Bertuzzi R, McGinley C, Lima-Silva AE. Separate and combined effects of caffeine and sodium-bicarbonate intake on judo performance. Int J Sports Physiol Perform, 2016; 11(2): $221-226$

Foskett A, Ali A, Gant N. Caffeine enhances cognitive function and skill performance during simulated soccer activity. Int J Sport Nutr Exerc Metab, 2009; 19(4): 410-423

Franchini E, Artioli GG, Brito CJ. Judo combat: Time-motion analysis and physiology. Int J Perform Anal Sport, 2013; 13(3): 624-641

Franchini E, Brito CJ, Fukuda DH, Artioli GG. The physiology of judo-specific training modalities. J Strength Cond Res, 2014; 28(5): 1474-1481

Franchini E, Del Vecchio FB, Matsushigue KA, Artioli GG. Physiological profiles of elite judo athletes. Sports Med, 2011; 41(2): 147-166

Fredholm BB, Abbracchio MP, Burnstock G, Daly JW, Harden TK, Jacobson KA, Leff P, Williams M. Nomenclature and classification of purinoceptors. Pharmacol Rev, 1994; 46(2): 143-156

Goldstein E, Jacobs PL, Whitehurst M, Penhollow T, Antonio J. Caffeine enhances upper body strength in resistance-trained women. J Int Soc Sports Nutr, 2010; 7: 18

Granier PL, Dubouchaud H, Mercier BM, Mercier JG, Ahmaidi S, Préfaut CG. Effect of NaHCO3on lactate kinetics in forearm muscles during leg exercise in man. Med Sci Sports Exerc, 1996; 28(6): 692-697

(c) Editorial Committee of Journal of Human Kinetics 
Harris RC, Tallon MJ, Dunnett M, Boobis L, Coakley J, Kim HJ, Fallowfield JL, Hill CA, Sale C, Wise JA. The absorption of orally supplied $\beta$-alanine and its effect on muscle carnosine synthesis in human vastus lateralis. Amino Acids, 2006; 30(3): 279-289

Huang SH, Johnson K, Pipe AL. The use of dietary supplements and medications by Canadian athletes at the Atlanta and Sydney olympic games. Clin J Sport Med, 2006; 16(1): 27-33

Hung W, Liu TH, Chen CY, Chang CK. Effect of $\beta$-hydroxy- $\beta$-methylbutyrate Supplementation During Energy Restriction in Female Judo Athletes. J Exerc Sci Fitness, 2010; 8(1): 50-53

Kalmar JM. The influence of caffeine on voluntary muscle activation. Med Sci Sports Exerc, 2010; 37(12): 21132119

Kim J, Cho HC, Jung HS, Yoon JD. Influence of performance level on anaerobic power and body composition in elite male Judoists. J Strength Cond Res, 2011; 25(5): 1346-1354

Kornasio R, Riederer I, Butler-Browne G, Mouly V, Uni Z, Halevy O. $\beta$-hydroxy- $\beta$-methylbutyrate (HMB) stimulates myogenic cell proliferation, differentiation and survival via the MAPK/ERK and PI3K/Akt pathways. Biochim Biophys Acta, 2009; 1793(5): 755-763

Kreider RB, Kalman DS, Antonio J, Ziegenfuss TN, Wildman R, Collins R, Candow DG, Kleiner SM, Almada AL, Lopez HL. International Society of Sports Nutrition position stand: Safety and efficacy of creatine supplementation in exercise, sport, and medicine. J Int Soc Sports Nutr, 2017; 14(1): 18

Lancha Junior AH, de Salles Painelli V, Saunders B, Artioli GG. Nutritional Strategies to Modulate Intracellular and Extracellular Buffering Capacity During High-Intensity Exercise. Sports Med, 2015; 45: 71-81

Latini S, Pedata F. Adenosine in the central nervous system: Release mechanisms and extracellular concentrations. J Neurochem, 2001; 79(3): 463-484

Lopes-Silva JP, Felippe LJC, Silva-Cavalcante MD, Bertuzzi R, Lima-Silva AE. Caffeine ingestion after rapid weight loss in judo athletes reduces perceived effort and increases plasma lactate concentration without improving performance. Nutrients, 2014; 6(7): 2931-2945

López-González LM, Sánchez-Oliver AJ, Mata F, Jodra P, Antonio J, Domínguez R. Acute caffeine supplementation in combat sports: a systematic review. J Int Soc Sports Nutr, 2018; 15(1): 60

Lopez-Grueso R, Aracil A, Sarabia JM, Montero C. Beta-alanine supplementation seems to increase physical performance and acute recovery in competitive judokas. Eur J Hum Movement, 2014; 33: 123-136

Lopez-Samanes A, Moreno-Perez D, Mate-Munoz JL, Dominguez R, Pallares JG, Mora-Rodriguez R, Ortega JF. Circadian rhythm effect on physical tennis performance in trained male players. J Sports Sci, 2017; 35(21): 2121-2128

Maté-Muñoz JL, Lougedo JH, Barba M, Garcia-Fernandez P, Garnacho-Castano MV, Dominguez R. Muscular fatigue in response to different modalities of CrossFit sessions. PLoS One, 2017; 12(7): e0181855

Maughan RJ, Burke LM, Dvorak J, Larson-Meyer DE, Peeling P, Phillips SM, Rawson ES, Walsh NP, Garthe I, Geyer H, Meeusen R, Van Loon L, Shirreffes SM, Spriet LL, Stuart M, Vernec A, Currell K, Ali VM, Budgett RGM, Ljunqvist A, Mountjoy M, Pitsiladis Y, Soligard T, Erdener U, Engebretsen L. IOC consensus statement: Dietary supplements and the high-performance athlete. Int J Sport Nutr Exerc Metab, 2018; 28(2): 104-125

McLellan TM, Caldwell JA, Lieberman HR. A review of caffeine's effects on cognitive, physical and occupational performance. Neurosci Biobehav Rev, 2016; 71: 294-312

Mohr M, Nielsen JJ, Bangsbo, J. Caffeine intake improves intense intermittent exercise performance and reduces muscle interstitial potassium accumulation. J Appl Physiol, 2011; 111(5): 1372-1379

Mora-Rodriguez R, Garcia Pallares J, Lopez-Samanes A, Ortega JF, Fernandez-Elias VE. Caffeine ingestion reverses the circadian rhythm effects on neuromuscular performance in highly resistance-trained men. PLoS One, 2012; 7(4): e33807

Pallarés JG, Fernández-Elías VE, Ortega JF, Muñoz G, Muñoz-Guerra J, Mora-Rodríguez R. Neuromuscular responses to incremental caffeine doses: Performance and side effects. Med Sci Sports Exerc, 2013; 
45(11): 2184-2192

Persky AM, Brazeau GA. Clinical pharmacology of the dietary supplement creatine monohydrate. Pharmacol Rev, 2001; 53(2): 161-176

Price M, Moss P. The effects of work:rest duration on physiological and perceptual responses during intermittent exercise and performance. J Sports Sci, 2007; 25(14): 1613-1621

Quinn PJ, Boldyrev AA, Formazuyk VE. Carnosine: Its properties, functions and potential therapeutic applications. Mol Aspects Med, 1992; 13(5): 379-444

Robertson RJ, Falkel JE, Drash AL, Metz KF, Spungen SA, LeBoeuf JR. Effect of induced alkalosis on physical work capacity during arm and leg exercise. Ergonomics, 1987; 30(1): 19-31

Ruijter J, De Ruiter MB, Snel J. The effects of caffeine on visual selective attention to color: an ERP study. Psychophysiology, 2000; 37(4): 427-439

Saunders B, Elliott-Sale K, Artioli GG, Swinton PA, Dolan E, Roschel H, Sale C, Gualano B. $\beta$-Alanine supplementation to improve exercise capacity and performance: A systematic review and metaAnalysis. Br J Sports Med, 2017; 51(8): 658-669

Siegler JC, Marshall PW, Bishop D, Shaw G, Green S. Mechanistic Insights into the Efficacy of Sodium Bicarbonate Supplementation to Improve Athletic Performance. Sports Med Open, 2016; 2(1): 41

Simmonds MJ, Minahan CL, Sabapathy S. Caffeine improves supramaximal cycling but not the rate of anaerobic energy release. Eur J Appl Physiol, 2010; 109(2): 287-295

Smith HJ, Wyke SM, Tisdale MJ. Mechanism of the attenuation of proteolysis-inducing factor stimulated protein degradation in muscle by beta-hydroxy-beta-methylbutyrate. Cancer Res, 2004; 64(23): 87318735

Souissi M, Abedelmalek S, Chtourou H, Atheymen R, Hakim A, Sahnoun Z. Effects of morning caffeine' ingestion on mood States, simple reaction time, and short-term maximal performance on elite judoists. Asian J Sports Med, 2012; 3(3): 161-168

Souissi M, Abedelmalek S, Chtourou H, Boussita A, Hakim A, Sahnoun Z. Effects of time-of-day and caffeine ingestion on mood states, simple reaction time, and short-term maximal performance in elite judoists. Biol Rhythm Res, 2013; 44(6): 897-907

Souissi M, Aloui A, Chtourou H, Aouicha HB, Atheymen R, Sahnoun Z. Caffeine ingestion does not affect afternoon muscle power and fatigue during the Wingate test in elite judo players. Biol Rhythm Res, 2015; 46(2): 291-298

Stellingwerff T, Anwander H, Egger A, Buehler T, Kreis R, Decombaz J, Boesch C. Effect of two beta-alanine dosing protocols on muscle carnosine synthesis and washout. Amino Acids, 2012; 42(6): 2461-2472

Sterkowicz S, Tyka AK, Chwastowski M, Sterkowicz-Przybycień K, Tyka A, Klys A. The effects of training and creatine malate supplementation during preparation period on physical capacity and special fitness in judo contestants. J Int Soc Sports Nutr, 2012; 9(1): 41

Swietach P, Youm JB, Saegusa N, Leem CH, Spitzer KW, Vaughan-Jones RD. Coupled Ca2+/H+ transport by cytoplasmic buffers regulates local Ca2+ and H+ ion signaling. Proc Natl Acad Sci, 2013; 110(22): 20642073

Taylor AD, Bronks R, Bryant AL. The relationship between electromyography and work intensity revisited: a brief review with references to lacticacidosis and hyperammonia. Electromyogr Clin Neurophysiol, 37(7): 387-398, 1997

Teixeira FJ, Matias CN, Monteiro CP, Valamatos MJ, Reis JF, Batista A, Oliveira AC, Sardinha LB, Phillips SM. No effect of HMB or $\alpha$-HICA supplementation on training-induced changes in body composition. Eur J Sport Sci, 2018; 27: 1-9

Tobias G, Benatti FB, de Salles Painelli V, Roschel H, Gualano B, Sale C, Harris RC, Lancha AH Jr, Artioli GG. Additive effects of beta-alanine and sodium bicarbonate on upper-body intermittent performance. Amino Acids, 2013; 45(2): 309-317

Tomlin DL, Wenger HA. The relationship between aerobic fitness and recovery from high intensity intermittent exercise. Sports Med, 2001; 31(1): 1-11 
van Duinen H, Lorist MM, Zijdewind I. The effect of caffeine on cognitive task performance and motor fatigue. Psychopharmacology, 2005; 180(3): 539-547

Volek JS, Kraemer WJ. Creatine Supplementation: Its Effect on Human Muscular Performance and Body Composition. J Strength Cond Res, 1996; 10(3): 200-210

Wilkinson DJ, Hossain T, Hill DS, Phillips BE, Crossland H, Williams J, Loughna P, Churchward-Venne TA, Breen L, Phillips SM, Etherdidge T, Rathmacher JA, Smith K, Szewczyk NJ, Atherton PJ. Effects of leucine and its metabolite $\beta$-hydroxy- $\beta$-methylbutyrate on human skeletal muscle protein metabolism. J Physiol, 2013; 591(11): 2911-2923

\section{Corresponding author:}

\section{Ángel Lago-Rodríguez}

Facultad de Ciencias de la Salud de la Universidad Isabel I. www.ui1.es.

Burgos. Spain.

C/Fernán González, 76. 09003. Burgos. Spain

Phone: +34 680330105

E-mail: angel.lago@ui1.es 